\title{
Reproductive cycle of the sea cucumber (Isostichopus fuscus) and its relationship with oceanographic variables at its northernmost distribution site
}

\author{
Abigail Pañola-Madrigal ${ }^{1}$, Luis E. Calderon-Aguilera ${ }^{1 *}$, Carlos A. Aguilar-Cruz ${ }^{2}$, \\ Héctor Reyes-Bonilla ${ }^{2} \&$ María Dinorah Herrero-Pérezrul ${ }^{3}$ \\ 1. Departamento de Ecología Marina, Centro de Investigación Científica y de Educación Superior de Ensenada, \\ Carretera Ensenada-Tijuana 3918, Ensenada, Baja California 22860, México; abys.victrix@gmail.com, \\ *leca@cicese.mx (corresponding author) \\ 2. Departamento Académico de Ciencias Marinas y Costeras, Universidad Autónoma de Baja California Sur, La Paz, \\ Baja California Sur, México; caguilar@uabcs.mx, hreyes@uabcs.mx \\ 3. Instituto Politécnico Nacional-Centro Interdisciplinario de Ciencias Marinas, La Paz, Baja California Sur; \\ dainoper@hotmail.com
}

Received 08-XII-2016. Corrected 10-V-2017. Accepted 07-VI-2017.

\begin{abstract}
The brown sea cucumber Isostichopus fuscus is highly prized and intensively fished, yet no studies of its reproductive cycle at its northernmost distribution site exist. To characterize its reproductive cycle, monthly surveys (Oct 2014-Dec 2016) that included gonad collection were conducted in 118 sites along the eastern coast of Baja California, including islands from Bahía San Luis Gonzaga (29 49' $14.18^{\prime}$ " N, $114^{\circ} 3^{\prime} 56.17^{\prime \prime}$ W) to the $28^{\text {th }}$ parallel north. A total of 2808 sea cucumber specimens were measured (mean length $\pm \mathrm{SD}=21.4 \pm 6 \mathrm{~cm}$ ) and weighed $(375.6 \pm 249 \mathrm{~g})$. Seven hundred and seventeen organisms were dissected but only 553 gonads were suitable for processing through histological analysis to identify sex and developmental stage. Of these individuals, 224 were female, 162 were male, 157 were undifferentiated and 10 were hermaphrodites, resulting in a sex ratio that was significantly different from $1: 1\left(\chi^{2}=36.63, \mathrm{P}=0.03, \mathrm{df}=23\right)$. There was no statistical difference $(p>0.05)$ of either size or weight between males and females, but females were larger than males. The length-weight relationship observed was $\mathrm{W}=0.18 \mathrm{~L}^{2.4}, \mathrm{r}^{2}=0.82, \mathrm{p}<0.05$ while the size-at-first-maturity was $16 \mathrm{~cm}$. Five gonad stages were identified: $28 \%$ undifferentiated, $9 \%$ gametogenesis, $15 \%$ mature, $19 \%$ expulsion and $29 \%$ post-expulsion. The Oocyte Theoretical Diameter (OTD) was estimated by measuring the area of 10291 oocytes, finding 2307 individuals in oogenesis (mean \pm SD of $65.3 \pm 19.7 \mu \mathrm{m}$ ), 3630 in maturity $(66.0 \pm 17.8 \mu \mathrm{m}), 3756$ in spawning $(73.8 \pm 14.6 \mu \mathrm{m})$ and 868 in post-spawning $(49.18 \pm 20.7 \mu \mathrm{m})$. Modal progression analysis shows that oocytes increase $23 \%$ in size from oogenesis to maturity, and decrease $9 \%$ in size from maturity to spawning and, on average, oocytes are $72 \%$ smaller post-spawning that during spawning. Rev. Biol. Trop. 65(Suppl. 1): S180-S196. Epub 2017 November 01.
\end{abstract}

Key words: reproduction; sea cucumber; Holothuroidea; oocyte diameter.

The brown sea cucumber Isostichopus fuscus (Ludwig, 1875) is an echinoderm of commercial importance with an elongated body and a soft, tough and thick border with irregular papules that inhabits rock bottoms, coral reefs and is occasionally found on sandy or soft bottoms, down to $61 \mathrm{~m}$ depth. This species is found from the Gulf of California to the Galapagos Islands and the coast of Ecuador (Deichmann,
1985; Maluf, 1988; Sonnenholzner et al., 2013; Toral-Granda \& Martínez, 2007). Its spatial distribution depends on substrate complexity, depth, temperature, salinity, light, rugosity, and food availability (Maluf, 1988).

In Mexico, I. fuscus was intensively fished from 1988 to 1993, with catches that surpasses 1000 tones shortly after, its abundance was so low that it was listed as an at-risk 
species by the Mexican government (NOM059-SEMARNAT-1994) and its fishing was completely banned (SEMARNAT, 1994). In 2002, the ban was suspended but fishing is dependent upon stock assessments (SEMARNAT, 2002) and currently the species is listed under special protection (SEMARNAT, 2010). This situation has motivated studies on the reproduction and growth (Herrero-Pérezrul, Reyes-Bonilla, García-Domínguez, \& Cintra-Buenrostro, 1999), population dynamics (Reyes-Bonilla \& Herrero-Pérezrul, 2003) fishery (Herrero-Pérezrul \& Chávez, 2005), weight-length relationships and condition index (Herrero-Pérezrul \& Reyes-Bonilla, 2008) of the brown sea cucumber. However, all of these studies were conducted in the southern portion of the Baja California peninsula.

There are a number of studies of the reproduction and growth of the brown sea cucumber that suggest that sea surface temperature, light, dissolved oxygen concentration, $\mathrm{pH}$, and the concentration of ammonia, nitrites and inorganic phosphorous are variables that influence the optimal development of this species (Asha \& Muthiah, 2005). Five gonad stages have been described for this species: I) undifferentiated, II) gametogenesis, III) maturity, IV) spawning and V) post-spawning (Fajardo-León, MichelGuerrero, Singh-Cabanillas, Vélez-Barajas, \& Massó-Rojas, 1995). It has also been observed that spawning coincides with rising temperatures and increased light (Fajardo-León et al., 1995; Herrero-Pérezrul et al., 1999; ToralGranda \& Martínez, 2007). Reproduction follows a seasonal pattern in Baja California Sur, México (Herrero-Pérezrul et al., 1999). However, there are no reproductive studies of this species at the northernmost limits of its distribution. Therefore, the objective of this study was to describe the reproductive cycle of I. fuscus and to evaluate the potential effects of environmental conditions on the cycle. We hypothesized that rising temperature and increased chlorophyll $a$ concentration, a proxy for primary production, would promote gonad development.

\section{MATERIALS AND METHODS}

Study Area: The gulf of California (GC) has been divided in three faunistic regions (Brusca \& Brusca, 2002). The northern region is influenced by the Colorado river delta, with high salinity and sea surface temperatures (SST) ranging between $10^{\circ} \mathrm{C}$ in winter and up to $32^{\circ} \mathrm{C}$ in summer. The salinity and temperature distributions observed are driven by seasonal flows of heat and humidity, with strong tidal and convective mixing (Paden, Abbott, \& Winant, 1993; Soto-Mardones, Marinone, \& Parés-Sierra, 1999). The central region or Greater Islands region (Isla Tiburon and Angel de la Guarda) presents lower SST due to intense tidal mixing, with strong seasonal changes from $16^{\circ} \mathrm{C}$ in winter to $31^{\circ} \mathrm{C}$ in summer (Álvarez-Borrego, 2007). The southern region or mouth of the gulf, is characterized by high primary productivity due to high nutrient concentrations that come from wind-induced upwelling, tidal mixing and the exchange of water masses between the gulf and the Pacific Ocean (Álvarez-Borrego, 2007; Lavín \& Marinone, 2003).

Field work: Sampling surveys were conducted monthly from October 2014 to December 2016 in 118 sites located in the northern and central regions of the GC. For logistic reasons the area was divided in three zones (Fig. 1). At each site SST, bottom temperature, salinity, dissolved oxygen and salinity were recorded with a sonde (YSI 85). Collection was performed by night because sea cucumbers hide during daylight (Reyes-Bonilla, Ramírez-Ortiz, Herrero-Pérezrul, \& Calderón-Aguilera, 2016) at three depths: shallow (1-9 m), mid-water (10-17 $\mathrm{m})$ and deep (18-27 m). All specimens found along $2 \times 25 \mathrm{~m}$ transects (two transects per depth, i.e., six transects per site) were collected and taken on board. Once aboard all specimens were left resting and then weighed (OHAUS ${ }^{\mathrm{MR}}$; precision $0.1 \mathrm{~g}$ ) and sized with a flexible tape $(1 \mathrm{~mm})$ and returned on site. Only 30 specimens were kept for histological analysis in each monthly survey. The gonad was 


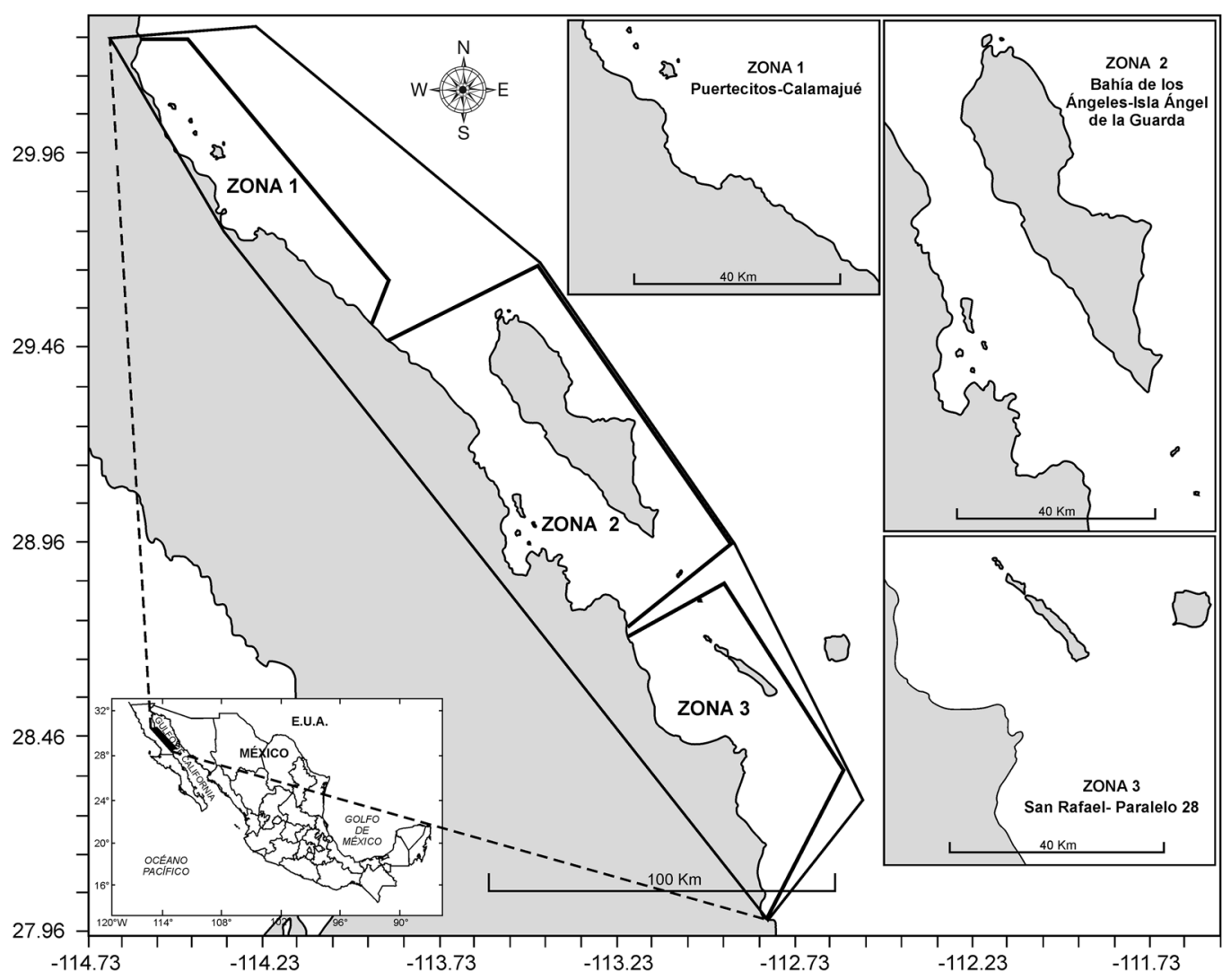

Fig. 1. Study area. Zoning division for sampling logistics purposes.

extracted and preserved in $10 \%$ formalin for three days and then transferred to $70 \%$ alcohol for histology.

Lab work: A portion of gonad was fixed in formaldehyde solution (10\%) for approximately $24 \mathrm{~h}$, dehydrated in a graded alcohol series, cleared with xylene and embedded in paraplast at $56^{\circ} \mathrm{C}$. Histological sections $(4 \mu \mathrm{m})$ were cut with a Leica 2040 Autocut microtome and stained with hematoxylin and eosin, following Humason (1962) and Bancroft, Cook, \& Stirling (1988). Gametogenic development and sex ratios were determined by examination of histological samples at different magnifications (4X,10X, 20X and 40X; Microscope Nikon Optiphot-II, coupled with a digital camera Sight DS-5M and the digital system Digital Sight DS-L1; Table 2 supplemental material).
Data analysis: Satellite data of monthly mean of chlorophyll a (Chl a) concentration and sea surface temperature (SST) with a 4 x $4 \mathrm{~km}$ pixel resolution from October 2014 to December 2016 were gathered from AQUAMODIS (Ocean Color Web http:// oceancolor.gsfc.nasa.gov/cms/) and processed with SeaDAS (ver. 7.3.1). A time series from 2003-2016 of Chl $a$ and SST were generated using NASA's Ocean Color Radiometry Online Visualization and Analysis Tool utility (https://giovanni.sci.gsfc.nasa.gov/giovanni/). These series were standardized $(\mu=0, \mathrm{SD}=1)$ to compare them with those observed during the study period. A cross-correlation analysis was performed to determine whether the timing of gametogenic development and spawning was correlated with $\mathrm{Chl} a$ concentration and SST using STATISTICA (Statsoft ver. 7.1). 
The weight - length relationship was described with a power model of the form $W$ $=a \cdot L^{b}$, where $W$ is weight, $L$ is length, $a$ is the intercept and $b$ is the allometry coefficient (Safran, 1992). The growth parameters were estimated through the Von Bertalanffy equation: $\mathrm{L}_{\mathrm{t}}=\mathrm{L}_{\infty}\left(1-\left[\mathrm{e}^{-\mathrm{k}(\mathrm{t}-\mathrm{t} 0)}\right]\right)$, where $L_{t}$ is the size or mean length at age $t$ and $\mathrm{L}_{\infty}$ is the maximum theoretical length that an individual can reach, $k$ is the growth rate and $t_{0}$ is an initial fitting parameter. This was done using the ELEFAN routine (Electronic Frequency Analysis) from FiSAT (ver. 1.2.2) (C FAO 2006-2016), following Gayanilo \& Pauly (1997). A $\chi^{2}$ test was performed to test if the sex ratio was $1: 1$. The oocyte area was estimated using ImageJ 1.46 (http://imagej.net/ImageJ). A total of 10291 oocytes that were contained within a field and presented a well-defined germinal vesicle were measured. The oocytes theoretical diameter (OTD) was calculated through the equation $\mathrm{OTD}=\sqrt{4} \mathrm{~A} / \pi$, where $O T D$ is in $\mu \mathrm{m}, A$ is the oocyte area and $\pi$ is a constant (Saout, Quéré, Donval, Paulet, \& Samain, 1999). In order to identify if there was more than one cohort, a modal progression analysis of OTD (Hmida, Ayache, Haouas, \& Romdhane, 2010) was performed using ELEFAN from FiSAT II.

\section{RESULTS}

A total of 2808 specimens of Isostichopus fuscus from 25 months of sampling (October 2014-October 2015 and January-December 2016) were evaluated. The mean length observed $( \pm \mathrm{SD})$ was $21.4 \pm 6.0 \mathrm{~cm}$ (min: $5 \mathrm{~cm}$, max: $41 \mathrm{~cm}$; Table 1 Supplemental Material). From the length frequency distribution depicted in Figure 2, the minimum size $(5 \mathrm{~cm})$ was recorded in October 2014 and March 2015 and the maximum $(41 \mathrm{~cm})$ in December 2014. The mean weight was $375.6 \pm 249.1 \mathrm{~g}$ (min: 4 g, recorded in May 2015, max: 1200 g, recorded in June 2015 and in June, July and October 2015; Table 1 supplemental material) and the frequency distribution is shown in Figure 3. The best represented weight class was 301-400 g; on average, males were bigger than females, but the difference was not statistically significant for either length $(t=-0.98$,

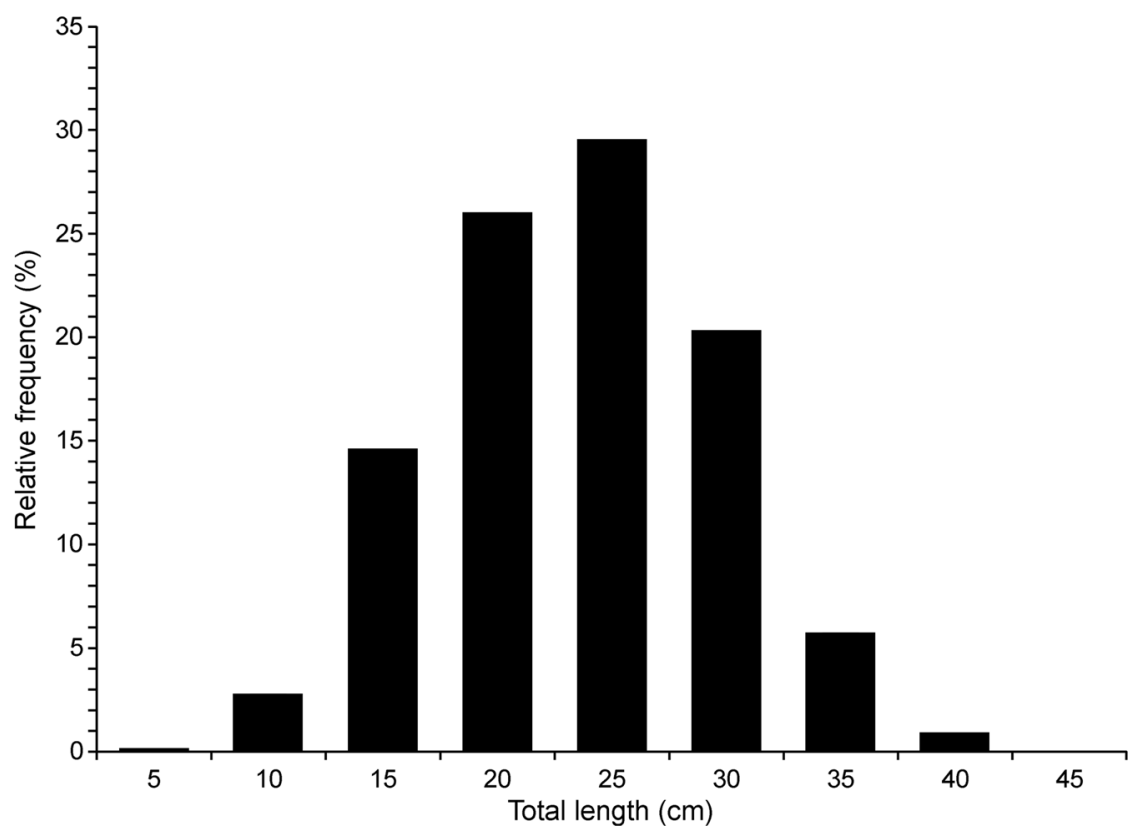

Fig. 2. Relative frequency (\%) of total length (cm) of Isostichopus fuscus collected during the 25 months of sampling period $(n=2,808)$. 
$\mathrm{P}>0.05, \mathrm{df}=381)$ or weight $(t=-1.79$, $\mathrm{P}>0.05, \mathrm{df}=379$ ).

Five hundred and fifty-three gonads were obtained from 717 dissected organisms, from which 224 were females, 162 were males, 157 were undifferentiated and 10 were hermaphrodites (Fig. 4). The sex ratio was statistically different from 1:1 $\left(\chi^{2}=36.63, \mathrm{P}=0.03, \mathrm{df}=23\right)$. Sexually active specimens accounted for $77 \%$ of the sample with a mean length of $27.5 \pm 4.06$ $\mathrm{cm}$ (min: 16, max: $41 \mathrm{~cm}$ ) and weight of $647 \pm$ $224 \mathrm{~g}$ (min: $50 \mathrm{~g}$, max: 1,200 g).

The weight-length relationship is described as $\mathrm{W}=0.18 \mathrm{~L}^{2.4}\left(\mathrm{r}^{2}=0.82\right)$. The Von Bertalanffy parameters are $\mathrm{L}_{\mathrm{t}}=39.9 \mathrm{~cm}$ and $\mathrm{k}=0.18$, supposing $\mathrm{at}_{0}=0$. With those parameters, the size-at-first maturity is estimated to be between 16 and $18 \mathrm{~cm}$.

Histological characteristics: Five stages of gonadal development were identified: undifferentiated, gametogenesis (oogenesis and spermatogenesis), maturity, spawning (spawning and expulsion), post-spawning (post-spawning and post-expulsion, Table 2 supplementary material, Fig. 6). For both sexes, the gonad consists of beams of numerous tubules of different lengths of white to beige coloration.

\section{Undifferentiated}

From all examined gonads, 28\% were undifferentiated and they were present throughout the year but more frequently from December to March (Fig. 5). At this stage, it is impossible to distinguish sex, because there are no gametes, only abundant conjunctive tissue and a thick gonadal wall. In some cases it was possible to observe phagocytes; this stage may be present in juvenile specimens or specimens that have passed the post-spawning stage, as the gonad is reabsorbed.

\section{Gametogenesis}

Only $9 \%$ of the sample was found at this stage. Specimens in the gametogenesis stage were observed from February to October and more frequently from April to August (Fig. 5). At this stage there is a proliferation of female and male gametes.

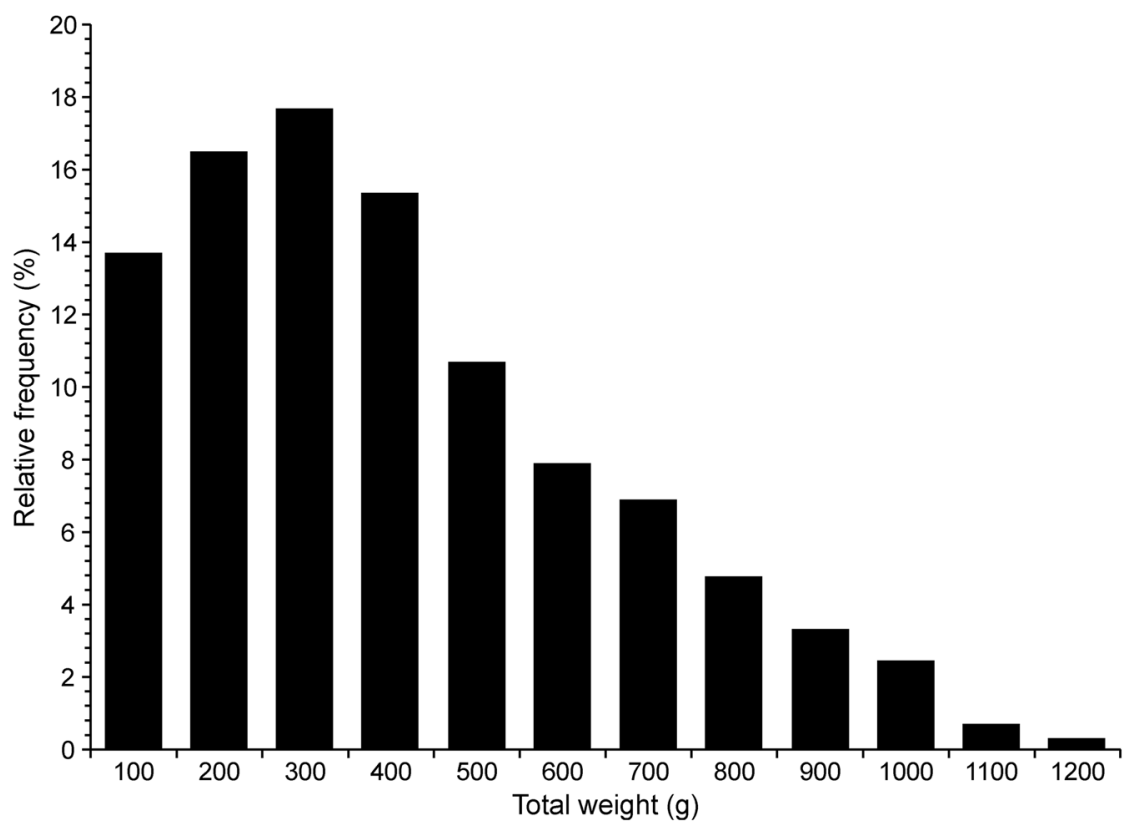

Fig. 3. Relative frequency (\%) of total weight (g) of Isostichopus fuscus collected during the 25 months of sampling period $(n=2,793)$. 


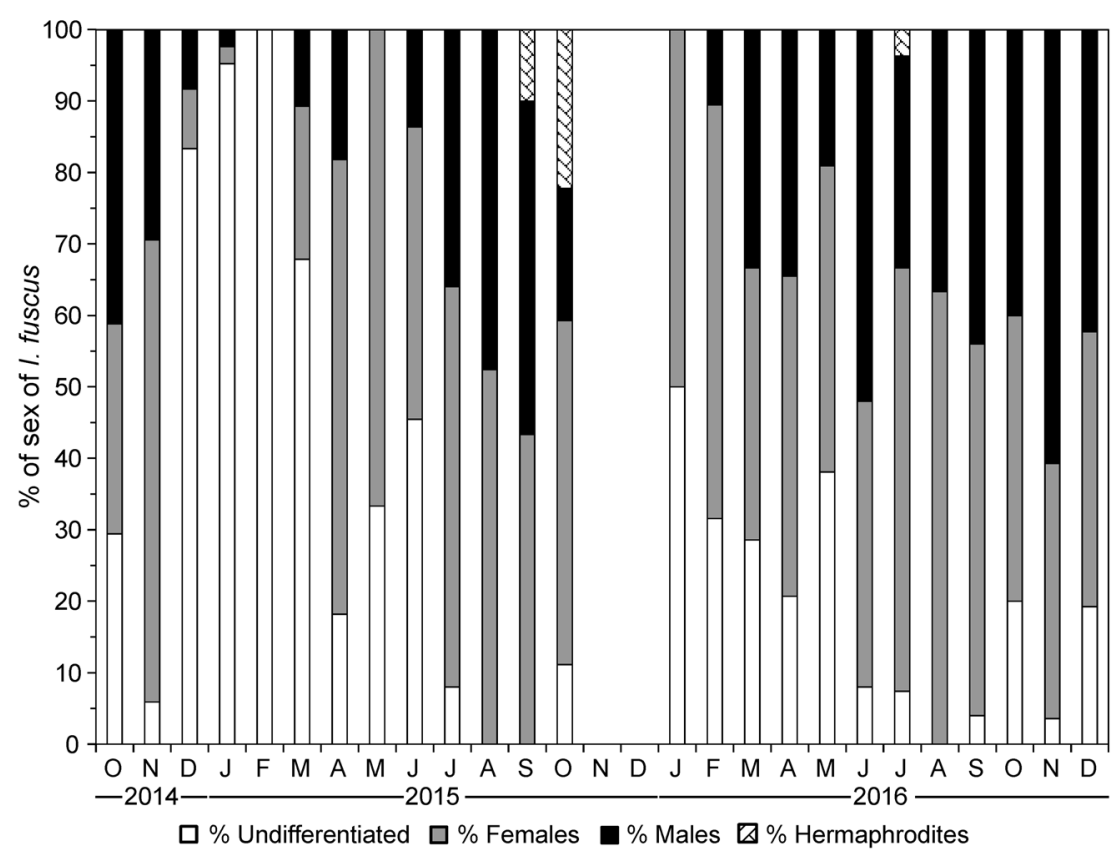

Fig. 4. Monthly proportion (\%) of sex of Isostichopus fuscus specimens along the 25-month sampling period $(\mathrm{n}=553)$.

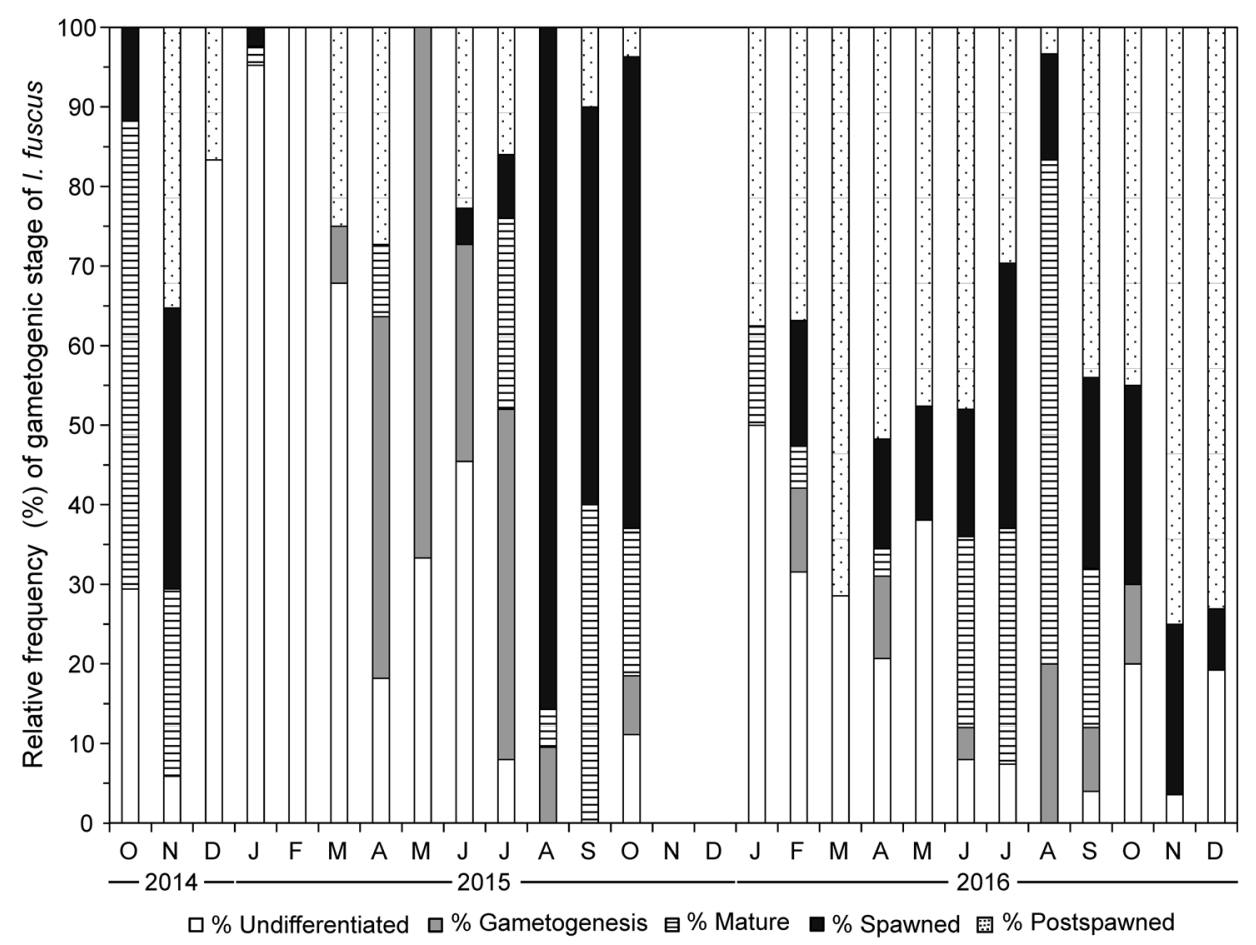

Fig. 5. Gonadal development of Isostichopus fuscus specimens collected during 25 months of sampling. 


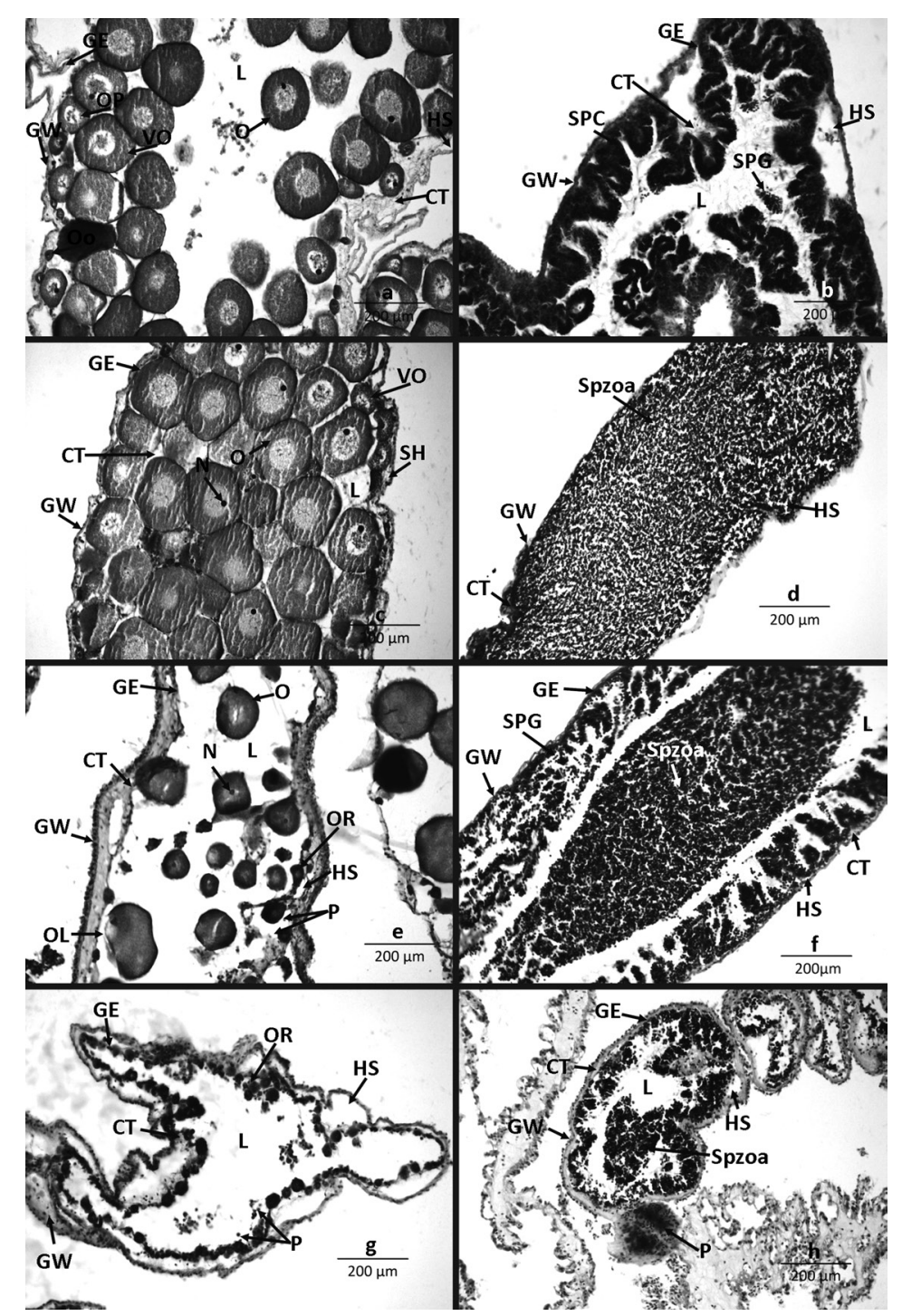

Fig. 6. Stages of gonadal development in gonads of females (a, c, d, f) and males (b, d, e, f) of Isostichopus fuscus. a) Oogenesis, b) spermatogenesis, c and d) maturity, e) spawning, f) expulsion, g) post-spawning, h) post-expulsion. GE: germinal epithelium, CT: connective tissue, HS: hemal sinus; GW: gonadal wall, L: lumen. Oo: oogonia, N: nucleus, VO: vitellogenic oocyte, OP: previtellogenic oocyte, OL; ovaries in lysis, OR: ova in reabsorption, SPC: spermatid columns, Spzoa: spermatozoa, P: phagocytes.

Oogenesis: In the gonad wall, oogonia are embedded or attached to the germinal epithelium, proliferating towards the lumen. Primary oocytes have a defined nucleus and peripheral nucleoli. In some cases, small cells (two or three products of meiosis) are seen around the primary oocyte. A large amount of connective tissue is observed, as well as folds in the wall of the gonad, which are reduced as gametogenesis progresses (Fig. 6 a).

Spermatogenesis: In spermatogenesis, the gonadal wall has longitudinal folds that extend towards the lumen and on the periphery of the wall there are spermatogonia of spherical appearance. There is proliferation 
of primary spermatocytes of ovoid and lumpy aspect and spermatocytes are seen arranged in folds. Mature spermatocytes can be observed in the lumen. The connective tissue begins to decrease in thickness by the accumulation of spermatocytes (Fig. 6 b).

\section{Maturity}

Fifteen percent of the collected sample were classified as mature. Mature specimens were observed from June to November, with a peak in the months of July to October (Fig. 5). At this stage, the gametes fill most of the light in the follicles. In females, the mature oocyte is completely round, measuring approximately $70 \mu \mathrm{m}$. The nucleus of the oocyte is easily distinguishable and it is possible to observe the three peripheral nuclei, as well as developing oocytes. The gonadal wall is thin and no connective tissue is visible. Although uncommon, the presence of atresia in the lumen can be observed, surrounded by phagocytes. Phagocytes are observed inside and outside the lumen (Fig. 6 c). In males, the follicles are completely saturated with mature spermatozoa, arranged in dense layers. Mature spermatozoa have a spherical shape, flattened slightly in the dorsoventral direction. The gonadal wall is thin and completely deployed, on the periphery there are spermatocytes and spermatids (Fig. 6 d).

\section{Spawning}

Nineteen percent of the sample was in the spawning stage, often in the months of August to October (Fig. 5). In this stage, a decrease of the gametes inside the follicles is observed, as well as empty spaces in the lumen.

Spawning: In this stage, little folds are observed in the gonadal wall, as well as a thickening of the gonadal wall and increasing connective tissue. The residual oocytes are in maturity or oogenesis. A large quantity of phagocytes are observed inside and outside the lumen. In some cases it is possible to observe the gametes in atresia (Fig. 6 e).
Expulsion: A separation between the mature spermatocytes at the center of the lumen and the immature spermatocytes at the periphery of the follicles is observed. The gonadal wall remains thin, although a thin layer of connective tissue is observed. It is possible to observe phagocytes (Fig. $6 \mathrm{f}$ ).

\section{Post-spawning}

Twenty nine percent of the sample was in the post-spawning stage, mostly present in November and December (Fig. 5). At this stage, the lumen of the follicles is practically empty. The gonadal wall is thick and has a large amount of connective tissue. A large quantity of phagocytes are observed inside and outside of follicles. The gonad is practically reabsorbed by phagocytic activity.

Post-spawning: The oocytes present are amorphous and of smaller size, clearly distinguishable atresia in different sizes (Fig. 6 g).

Post-expulsion: Distinction between spermatozoa and phagocytes is difficult, since the remaining spermatozoa are being phagocytosed (Fig. 6 h).

\section{Hermaphrodite}

Two percent $(n=10)$ of the sexed specimens were hermaphroditic (Fig. 7). Nine of the ten hermaphroditic organisms were collected in San Luis Gonzaga in the months of September and October of 2015 (Fig. 5). Female and male follicles were found in different gonadal stages, and three specimens were in spawning stage. In four specimens, female follicles were spawning and male follicles were in gametogenesis and in two specimens, female follicles were mature and male follicles were in gametogenesis. The other hermaphroditic specimen was collected in San Francisquito in July 2016; in this specimen both female and male follicles were spawning.

Gametogenic stage and environmental variables: For the study period, Chl $a$ SST 


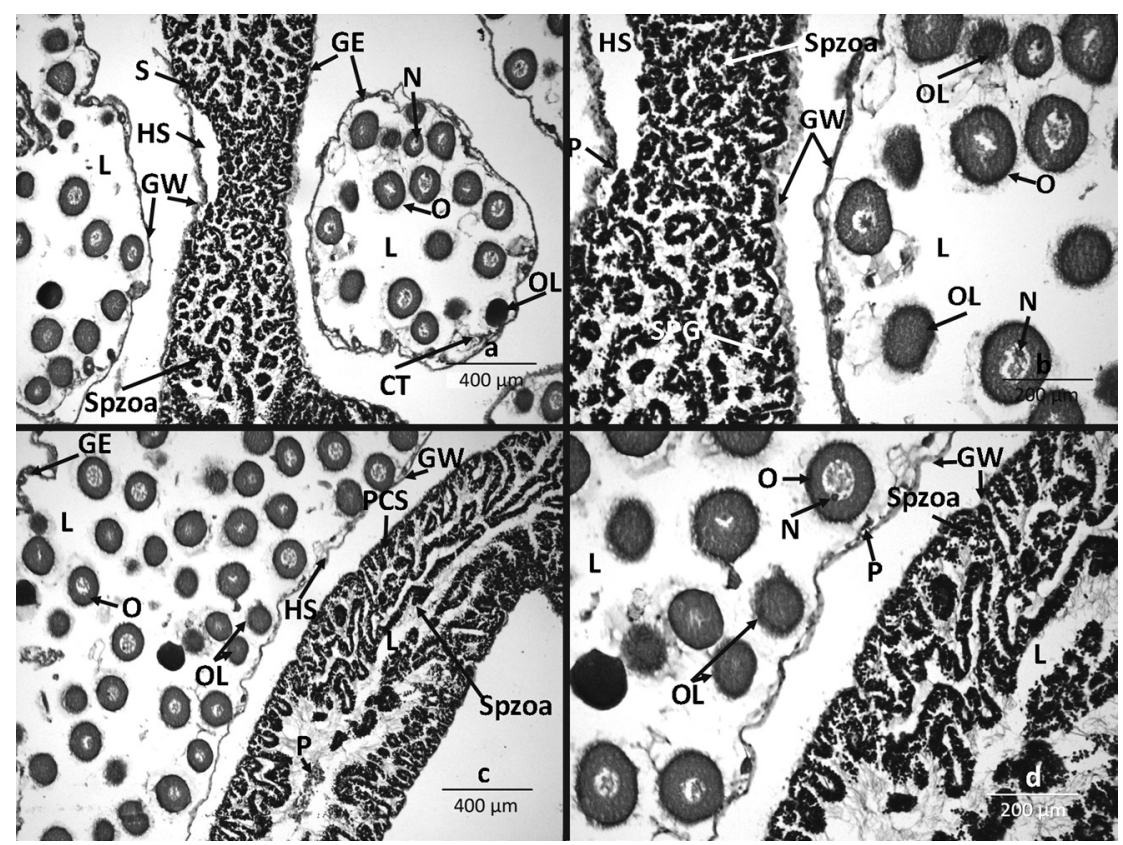

Fig. 7. Stages of gonadal development in hermaphroditic gonads of Isostichopus fuscus. GE: germinal epithelium, CT: connective tissue, HS: hemal sinus; GW: gonadal wall, L: lumen. Oo: oogonia, N: nucleus, VO: vitellogenic oocyte, OP: previtellogenic oocyte, OL; ovaries in lysis, OR: ova in reabsorption, SPC: spermatid columns, Spzoa: spermatozoa, P: phagocytes. In both images the female follicles were spawning and the male follicles in gametogenesis.

anomalies were observed and compared to historical values. Even when SST followed a seasonal pattern $\left(\min 17^{\circ} \mathrm{C}\right.$ in winter and $31^{\circ} \mathrm{C}$ max in summer), there was a large difference in October 2015 of $6.5^{\circ} \mathrm{C}$ higher than the historical average (Fig. 8). Chl $a$ follows an irregular pattern, with peaks in February, March, April and November, reaching a maximum of 5.96 $\mathrm{mg} \mathrm{Chl} a \mathrm{~m}^{-3}$ in February 2015, with means of $4.3 \mathrm{mg} \mathrm{Chl} a \mathrm{~m}^{-3}$ more than the historical average for that month. However, in 2016 there were negative anomalies in January, February, March, May, June, July, September and October compared to the historical average.

The reproductive peak occurs on June, coinciding with an increase in SST. The crosscorrelation analysis shows a positive correlation between gametogenesis and SST two months before the observed reproductive peak $(\mathrm{r}=0.42, \mathrm{P}<0.05)$. On the other hand, there is negative correlation between $\mathrm{Chl} a$ and gametogenesis $(\mathrm{r}=-0.65, \mathrm{P}<0.05)$ four months before gametogenic development. Gamete expulsion occurs from August to October, when SST is higher and this was corroborated by the cross-correlation analysis $(r=0.57$, $\mathrm{P}<0.05$ ). Moreover, there was a negative correlation between $\mathrm{Chl} a$ and gamete expulsion $(r=-0.71, P<0.05)$ when lag $=0$.

\section{Oocyte theoretical diameter (OTD) and} modal progression analysis (MPA): A total of 10291 oocytes were measured (mean $\pm \mathrm{SD}=$ $65.3 \pm 19 \mu \mathrm{m})$. The mean OTD during gametogenesis was $66.0 \pm 17 \mu \mathrm{m}), 73.8 \pm 14 \mu \mathrm{m}$ during maturity, $60.4 \pm 20 \mu \mathrm{m}$ during spawning and $49.2 \pm 20 \mu \mathrm{m}$ during post-spawning. The MPA shows that the OTD increases $23 \%$, i.e., $15 \mu \mathrm{m} \cdot \mathrm{month}^{-1}$ when passing from oogenesis to maturity, and decreases $9 \%\left(7 \mu \mathrm{m} \cdot \mathrm{month}^{-1}\right)$ when passing from maturity to spawning; finally, OTD in post-spawning is, on average, $53 \mu \mathrm{m} \cdot$ month $^{-1}$ smaller than during spawning. 


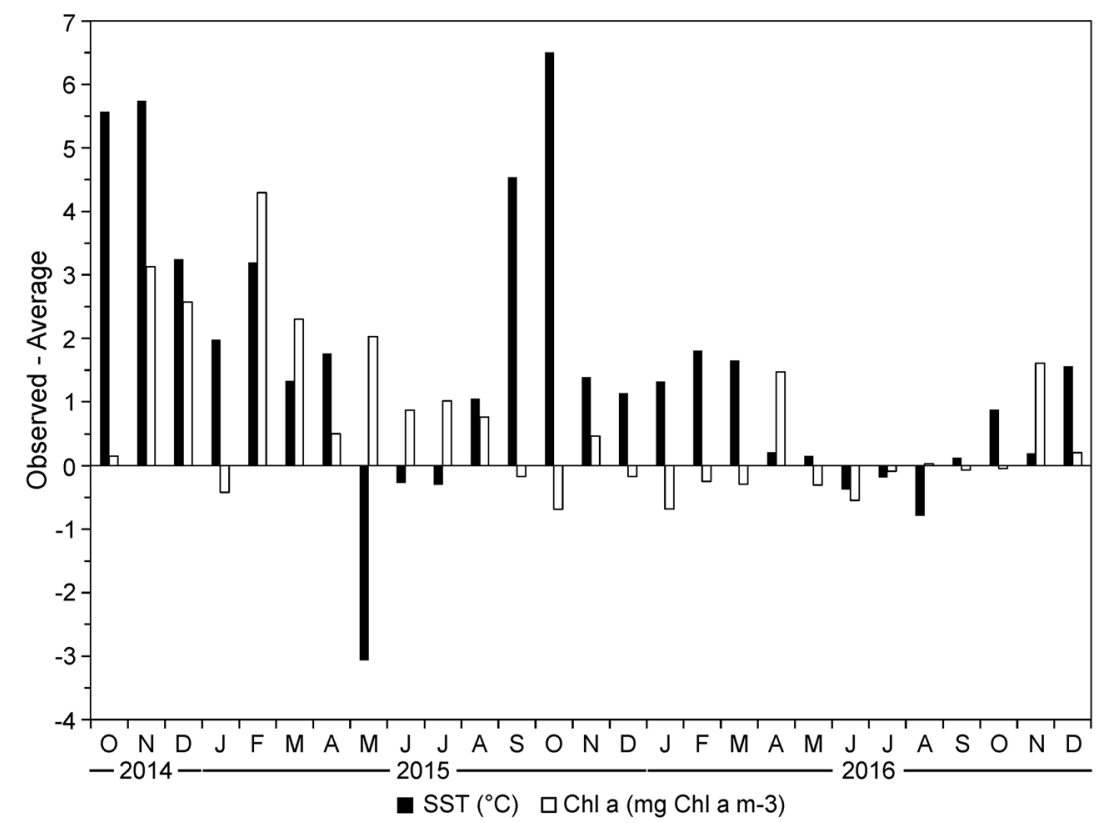

Fig. 8. Differences between the average monthly historical values and those observed during the study period of sea surface temperature (SST, ${ }^{\circ} \mathrm{C}$ ) and chlorophyll $a$ concentration ( $\mathrm{Chl} a, \mathrm{mg} \mathrm{Chl} a \mathrm{~m}^{-3}$ ). Historical SST: monthly average from 2003 to 2013. SST observed monthly average 2014 to 2016. Chl $a$ Historical: monthly average from 2003 to 2013. Chl $a$ in-situ: monthly average 2014 to 2016 .

\section{DISCUSSION}

In a seminal paper on echinoderm reproduction, Mercier \& Hamel (2009) affirm that every time there is more evidence that there are exogenous factors that affect the reproduction of these animals. This is the first work conducted at the northernmost limit of the distribution of Isostichopus fuscus, as well as the first to address the relationship between its reproductive cycle and environmental variables. This is of utmost importance considering that a population living at the limit of its distribution may be more sensitive to environmental variables and that may manifest as anomalies in gonadal development.

On average, sea cucumbers from the north of the gulf of California are smaller $(21.4 \mathrm{~cm})$ and lighter $(375.6 \mathrm{~g})$ than those from the central and southern regions of the gulf $\left(27^{\circ}\right.$ a 29 ${ }^{\circ} \mathrm{N}$; 25.1-32 cm and 458-562 g: Fajardo-León et al., 1995; Fajardo-León \& Vélez-Barajas, 1996 and $23.3 \mathrm{~cm}$ and 385.9g: Herrero-Pérezrul
\& Reyes-Bonilla, 2008) and Oaxaca, México $\left(16^{\circ} \mathrm{N} ; 396 \mathrm{~g}\right.$, Glockner-Fagetti \& BenítezVillalobos, 2017) but larger than in the Galápagos $\left(0^{\circ} \mathrm{N} ; 20 \mathrm{~cm}\right.$ and $271 \mathrm{~g}$ : Sonnenholzner, 1997 and $20.8 \mathrm{~cm}$ : Toral-Granda \& Martínez, 2007). Even when sizes may indicate a gradient from north to south, as proposed by HerreroPérezrul et al., (1999), it might also be the result of manipulation, as holothurids are very malleable. Conand, (1990) mentions that aspidoquirots commercial species such as Holothuria scabra, $H$. nobilis and $H$. fuscogilva have sizes larger than $28 \mathrm{~cm}$ and may weigh over $900 \mathrm{~g}$. Size is very important for fisheries and commercial purposes as $90 \%$ of body weight is lost during dehydration (Herrero-Pérezrul \& Reyes-Bonilla, 2008).

The total weight frequency distribution of I. fuscus was found to be between $4-1200 \mathrm{~g}$, with specimens most frequent falling between 200-400g. Toral-Granda \& Martínez (2007) consider juveniles to be those individuals below 150 g. Following that criteria, 19\% 
of the sampled population in this study was juvenile. Moreover, Nuño-Hermosillo (2003) considered recruits to be specimens shorter than $13 \mathrm{~cm}$. Therefore, recruitment at our study region takes place between October and February, when $7 \%$ of the population was between 4-12 cm of length.

The smallest reproductively active organism of I. fuscus was $16 \mathrm{~cm}$ long; however, $50 \%$ of the population was sexually active at $\cong 25 \mathrm{~cm}$. In the south of the Baja California peninsula, size-at-fist-maturity was found at five years or at $21 \mathrm{~cm}$ long (Herrero-Pérezrul \& Chávez, 2005; Herrero-Pérezrul \& ReyesBonilla, 2008), which is very close to what was found in this study.

The weight-length parameters $a$ and $b$ have a biological meaning; in holothurids $35 \%$ of its weight is soft tissue (guts and gonads) and water; therefore, the weight-length relationship could be affected by manipulation, either by retention or expulsion of water. Our estimates of $a(0.18)$ and $b(2.4)$ are different from those of Fajardo-León et al., (1995; $a=0.60$ and $b$ $=1.6$ ) and Herrero-Pérezrul \& Reyes-Bonilla (2008; $a=1.6$ and $b=1.8$ ) for this species.

The 1:1 sex ratio is common in species with sexual reproduction (Hamel \& Mercier, 1996; Pennington, 1985) and this is the case for most holothurids, but not always. In the case of I. fuscus there is contradictory evidence regarding the sex ratio. In Mexico, HerreroPérezrul et al., (1999) found a 1:1 sex ratio, whereas in Ecuador, Toral-Granda \& Martínez (2007) found more females than males, as we found in this study. In another species of sea cucumber (Parastichopus parvimensis), Tapia Vázquez et al., (1996) observed that sex ratios varied monthly.

In our study area, I. fuscus exhibits an asynchronous reproductive cycle between sexes which is different from what other authors have observed in tropical regions (Conand, 1990; Fajardo-León et al., 1995; Tapia Vázquez et al., 1996). However, this same species may present continuous spawning (Toral-Granda \& Martínez, 2007) and those differences are related to environmental conditions. One caveat of our study is that we performed monthly surveys and we may have lost more frequent reproductive pulses. This limitation in reproductive studies has already been pointed out by Mercier \& Hamel (2009), but it is very difficult to overcome due to logistic and budgeting concerns. Nevertheless, 25 monthly surveys and the histological analysis of hundreds of gonads ensure that our study is representative of the gonad cycle of this species in the northern Gulf of California.

Gonad development starts in March becomes more active between April and July, when temperatures rise. Spawning takes place from June to November, with a peak during August and September, coinciding with higher temperatures. This relationship for holothurids has been observed by many authors (Drumm \& Loneragan, 2005; Guzmán, Guevara, \& Hernández, 2003; Hamel, Himmelman, \& Dufresne, 1993; Hamel \& Mercier, 1995; Muthiga, Kawaka, \& Ndirangu, 2009; Omar, Abdel Razek, Abdel Rahman, \& El Shimy, 2013; Ramofafia, Battaglene, Bell, \& Byrne, 2000; Ramofafia, Byrne, \& Battaglene, 2001).

The peak in Chl a concentration takes place in February, which might induce the reproductive process due to increased food availability for the system as a whole. Female gametogenesis starts one month earlier than in males, coinciding with the peak of primary productivity, perhaps because of the energetic cost of egg production. Hamel et al., (1993) observed that phytoplankton increase triggered spawning of Psolus fabricii; in our study, the increase in $\mathrm{Chl} a$ concentration triggers gametogenesis and spawning takes place during the warm season while undifferentiated individuals are present in the cold months.

The oocyte theoretical diameter (OTD) for other holothurids ranges between 8.93$119.83 \mu \mathrm{m}$ (Conand, 1982). Costelloe, (1985) found that OTD for Aslia lefevrei was between 40-220 $\mu \mathrm{m}$ in oogenesis, 250-340 $\mu \mathrm{m}$ when active and spawning and between 20-40 $\mu \mathrm{m}$ during post-spawning. In our study, we found a mean OTD of $66 \mu \mathrm{m}$ in oogenesis, $73.8 \mu \mathrm{m}$ when active, $60.4 \mu \mathrm{m}$ spawning and $49.2 \mu \mathrm{m}$ 
post-spawning, which is similar to results by Costelloe, (1985).

In marine organisms, there are many factors such as genetics, contaminants and overfishing that can influence hermaphroditism (Ghiselin, 1969). In the case of holothurids, HerreroPérezrul, Reyes-Bonilla, \& García-Dominguez, (1998) have reported very few cases: 2 out of 155 organisms for Holothuria atra, 1 out of 113 organisms for Peniagone azorica, 1 out of 30 organisms for P. diaphana and 1 out of 429 organisms for Cherbonniera utriculus. For $I$. fuscus this is the third case reported and the one with the largest proportion (2\%) of hermaphrodites: 10 out of 553 organisms. Previously, Herrero-Pérezrul et al. (1999) found 2 out of 173 and organisms, Nuño-Hermosillo (2003) reported one out of 165 organisms. Interestingly, all hermaphrodites came from San Luis Gonzaga, a location with a mining influence and the presence of heavy metals and pesticides (Servicio Geológico Mexicano, 2003). Even when the region has low human activity, resuspension of sediments, mining and mixing due to upwelling, are known to be a source and a means of transport of heavy metals. Moreover, high concentrations of $\mathrm{Mn}, \mathrm{Al}, \mathrm{Zn}, \mathrm{Cd}$ and $\mathrm{Cu}$ have been detected in mussels from the northern Gulf of California (Gutiérrez-Galindo, Villaescusa-Celaya, \& Arreola-Chimal, 1999). Avise (2011) mentions that heavy metals and metaloids affect the endocrine system, reproduction and other biological process. In our study, the hermaphrodites were present spawning as females and present in gametogenesis as males. It has been observed in dioic species that hermaphroditism increases with overfishing (Borgia \& Blick, 1981; Ghiselin, 1969). This last author claims that hermaphroditism may be an adaption to increase the chances of successful fertilization (Ghiselin, 1969). We suggest that mining, chemicals and fishing pressure might be driving hermaphroditism in the area.

On the other hand, asexual reproduction has been reported for holothurids (Dolmatov, 2014). Lawrence and Herrera (2000) mention that fission in holothurids seems to be related with habitat and it is induced environmentally and that is why some species draw on fission as an adaptation to sustain populations where recruitment is unlikely. In a recent work, Sonnenholzner, Searcy-Bernal, \& Panchana-Orrala, (2017) achieved asexual reproduction of $I$. fuscus through transverse fission. This is highly relevant for mariculture and restocking under the current depauperate condition of this species in the region (Glockner-Fagetti, CalderonAguilera, \& Herrero-Pérezrul, 2016).

One of the open questions of this work refers to the effect of fishing on reproduction, because current density is one order of magnitude less than ten years ago (GlocknerFagetti et al., 2016). In dioic organisms it is not clear how they synchronize to release gametes to find mature conspecifics. In I. fuscus Shepherd, Martinez, Toral-Granda, \& Edgar (2004) suggest that a density of 1.2 ind $\mathrm{m}^{-2}$ is needed in order to expect a $50 \%$ fertilization success. In our study area the mean density is $0.07 \mathrm{ind} \cdot \mathrm{m}^{-2}$, well below that density, so more studies on stock assessment and reproduction should be conducted.

\section{ACKNOWLEDGMENTS}

The first author received a scholarship during her Master's studies (CONACYT CVU 599881). T. Rubilar assisted with the description of gonad stages. B. Rojas performed the histological processing of samples collected in 2016. FJ Ponce assisted with graphic preparations. This work was supported by the Fondo Sectorial de Investigación en Materias, Agrícola, Pecuaria, Acuacultura, Agrobiotecnología y Recursos Fitogenéticos (SAGARPA-CONACYT, grant 2013-2-0225235 to LECA). Comments of two anonymous reviewers improved previous versions of this work. Professional proofreading by A. L. McTavish.

\section{RESUMEN}

El pepino de mar Isostichopus fuscus es un recurso de gran valor comercial, por lo cual es altamente explotado. Sin embargo, no hay estudios sobre su ciclo reproductivo en la zona más norteña de su distribución. Con el fin de 
caracterizar su periodo reproductivo, se realizaron expediciones mensuales (Oct 2014-Dic 2016), en la costa oriental de Baja California. Se visitaron 118 sitios comprendidos en la zona costera e insular desde Bahía San Luis Gonzaga hasta el Paralelo 28 para colectar gónadas. Se colectaron 2808 especímenes de $I$. fuscus, la talla media \pm desviación estándar fue de $21 \pm 6.7 \mathrm{~cm}$ y el peso medio fue $375.6 \pm 249$ g. Se disectaron 717 organismos, de los que se obtuvieron 553 gónadas. Mediante análisis histológico se identificó que 224 eran hembras, 162 machos, 157 indiferenciados y 10 hermafroditas. Se encontraron más hembras que machos $\left(\chi^{2}=36.63, \mathrm{P}=0.03, \mathrm{gl}=23\right)$. No hubo diferencias significativas ni en la longitud ni en el peso entre hembras y machos $(\mathrm{P}>0.05)$, sin embargo, las hembras fueron relativamente más grandes. La relación pesolongitud se describe con la ecuación $\mathrm{P}=0.18 \mathrm{~L}^{2.4}, \mathrm{r}^{2}=0.82$; la talla de primera madurez se calculó a los $16 \mathrm{~cm}$. Se identificaron cinco estadios de desarrollo gonádico, $28 \%$ de las gónadas se catalogaron como indiferenciadas, $9 \%$ en gametogénesis, $15 \%$ en madurez, $19 \%$ en expulsión y $29 \%$ en postexpulsión. Se estimó el diámetro teórico del ovocito (DTO) a partir de la medición del área de 10291 ovocitos. La media del DTO en ovogénesis fue de $65.3 \pm 19.7 \mu \mathrm{m}$, $(n=2037)$, en madurez fue de $66.0 \pm 17.8 \mu \mathrm{m}(\mathrm{n}=3630)$, en desove fue de $73.8 \pm 14.6 \mu \mathrm{m}(\mathrm{n}=3756)$ y en postdesove fue de $49.18 \pm 20.7 \mu \mathrm{m}(\mathrm{n}=868)$. El análisis de progresión modal indicó que los ovocitos al pasar de la ovogénesis a la madurez incrementan su DTO un $23 \%$, mientras que de la madurez al desove disminuyen $9 \%$, y en postdesove son en promedio $72 \%$ más chicos que en desove.

Palabras clave: reproducción; pepino de mar; Holothuroidea; diámetro de ovocitos.

\section{REFERENCES}

Álvarez-Borrego, S. (2007). Oceanografía de la región de las grandes islas. In G. D. Danemann \& E. Ezcurra (Eds.), Bahía de los Ángeles: recursos naturales y comunidad: linea base 2007 (pp. 45-65). Instituto Nacional de Ecología.

Asha, P. S., \& Muthiah, P. (2005). Effects of temperature, salinity and $\mathrm{pH}$ on larval growth, survival and development of the sea cucumber Holothuria spinifera Theel. Aquaculture, 250(3), 823-829.

Avise, J. C. (2011). Hermaphroditism: a primer on the biology, ecology, and evolution of dual sexuality. Columbia University Press.

Bancroft, J. D., Cook, H. C., \& Stirling, R. W. (1988). Manual of histological techniques and their diagnostic application. Churchill Livingstone.

Borgia, G., \& Blick, J. (1981). Sexual competition and the evolution of hermaphroditism. Journal of Theoretical Biology, 89(3), 523-532.
Brusca, R. C., \& Brusca, G. J. (2002). Invertebrates (2 ed). Sinauer Associates Incorporated.

Conand, C. (1982). Reproductive cycle and biometric relations in a population of Actinopyga echinites (Echinodermata: Holothuroidea) from the lagoon of New Caledonia, western tropical Pacific. In International Echinoderm Conference, Belkema, Rotterdam (pp. 437-442).

Conand, C. (1990). The Fishery Resourse of Pacific Island Countries: Part 2. Food \& Agriculture Org.

Costelloe, J. (1985). The annual reproductive cycle of the holothurian Aslia lefevrei (Dendrochirota: Echinodermata). Marine Biology, 88(2), 155-165.

Deichmann, E. (1985). The Holothurioidea collected by the Velero III during the years 1932 to 1938 . University of Suouthern California Press.

Dolmatov, I. (2014). Asexual reproduction in holothurians. The Scientific World Journal, 2014, 1-13.

Drumm, D. J., \& Loneragan, N. R. (2005). Reproductive biology of Holothuria leucospilota in the Cook Islands and the implications of traditional fishing of gonads on the population. New Zealand Journal of Marine and Freshwater Research, 39(1), 141-156.

Fajardo-León, M. del C., Michel-Guerrero, E., SinghCabanillas, J., Vélez-Barajas, J. A., \& Massó-Rojas, J. A. (1995). Estructura poblacional y ciclo reproductor del pepino de mar Isostichopus fuscus en Santa Rosalía, BCS, México. Ciencia Pesquera, 11, 45-53.

Fajardo-León, M. del C., \& Vélez-Barajas, A. (1996). Pesquería del pepino de mar. In M. Casas-Vladez \& G. Ponce-Díaz (Eds.), Estudio del potencial pesquero y acuícola de Baja California Sur (Vol. 2, pp. 151-165). La Paz: SEMARNAT/CICIMAR.

(C) FAO 2006-2016. Fisheries and aquaculture software. FISAT II - FAO-ICLARM Stock Assessment Tool. In: FAO Fisheries and Aquaculture Department [online]. Rome.

Gayanilo, F. C. J., \& Pauly, D. (1997). FAO-ICLARM Stock Assessment Tools (FiSAT). Reference Manual., 8, 261.

Ghiselin, M. T. (1969). The evolution of hermaphroditism among animals. The Quarterly Review of Biology, 44(2), 189-208.

Glockner-Fagetti, A., \& Benítez-Villalobos, F. (2016). Spatio-temporal variation in density and size structure of the endangered sea cucumber Isostichopus fuscus in Huatulco National Park, Mexico. Marine Ecology, 38(1), e12386. http://doi.org/10.1111/maec.12386

Glockner-Fagetti, A., Calderon-Aguilera, L. E., \& HerreroPérezrul, M. D. (2016). Density decrease in an exploited population of brown sea cucumber Isostichopus 
fuscus in a biosphere reserve from the Baja California peninsula, Mexico. Ocean \& Coastal Management, $121,49-59$.

Gutiérrez-Galindo, E. A., Villaescusa-Celaya, J. A., \& Arreola-Chimal, A. (1999). Bioacumulación de metales en Mejillones de cuatro sitios selectos de la región costera de Baja California. Ciencias Marinas, 25(4), 557-578.

Guzmán, H. M., Guevara, C., \& Hernández, I. (2003). Reproductive cycle of two commercial species of sea cucumber (Echinodermata: Holothuroidea) from Caribbean Panama. Marine Biology, 142(2), 271-279.

Hamel, J.-F., Himmelman, J. H., \& Dufresne, L. (1993). Gametogenesis and spawning of the sea cucumber Psolus fabricii (Duben and Koren). The Biological Bulletin, 184(2), 125-143.

Hamel, J.-F., \& Mercier, A. (1995). Spawning of the sea cucumber Cucumaria frondosa in the St. Lawrence Estuary, eastern Canada. Lawrence Estuary, Eastern Canada. SPC Beche-de-Mer Information Bulletin, 7, 12-18.

Hamel, J.-F., \& Mercier, A. (1996). Gonad morphology and gametogenesis of the sea cucumber Cucumaria frondosa. SPC Beche-de-Mer Information Bulletin, 8, 22-33.

Herrero-Pérezrul, M. D., \& Chávez, E. A. (2005). Optimum fishing strategies for Isostichopus fuscus (Echinodermata: Holothuroidea) in the Gulf of California, México. Revista de Biología Tropical, 53(3), 357.

Herrero-Pérezrul, M. D., \& Reyes-Bonilla, H. (2008). Weight-Length relationship and relative condition of the holothurian Isostichopus fuscus at Espíritu Santo Island, Gulf of California, México. Revista De Biologia Tropical, 56(3), 273-280.

Herrero-Pérezrul, M. D., Reyes-Bonilla, H., \& GarcíaDominguez, F. (1998). Casual hermaphroditism in gonochoric Isostichopus fuscus (Ludwig, 1875)(Echinodermata: Holothuroidea) of the southern Gulf of California, Mexico. Bulletin of Marine Science, 63(3), 611-615.

Herrero-Pérezrul, M. D., Reyes-Bonilla, H., GarcíaDomínguez, F., \& Cintra-Buenrostro, C. E. (1999). Reproduction and growth of Isostichopus fuscus (Echinodermata: Holothuroidea) in the southern Gulf of California, México. Marine Biology, 135(3), 521-532.

Hmida, L., Ayache, N., Haouas, Z., \& Romdhane, M. S. (2010). Oocyte cohort analysis: criteria for an evaluation of the reproductive cycle in Solen marginatus (Pennant, 1777),(Bivalvia: Solenacea) in southern Tunisia. Journal of Shellfish Research, 29(1), 129-134.
Humason, G. L. (1962). Animal Tissue Techniques. Animal tissue techniques. United States of America: W. H. Freeman and Company.

Lavín, M. F., \& Marinone, S. G. (2003). An overview of the physical oceanography of the Gulf of California. In Nonlinear processes in geophysical fluid dynamics (pp. 173-204). Springer.

Lawrence, J. M., \& Herrera, J. (2000). Stress and deviant reproduction in echinoderms. Zoological Studies, 39(3), 151-171.

Maluf, L. Y. (1988). Composition and distribution of the central eastern Pacific echinoderms (6th ed.). Los Angeles, California: Natural History Museum of Los Angeles County.

Mercier, A., \& Hamel, J. (2009). Endogenous and exogenous control of gametogenesis and spawning in echinoderms. Advances in Marine Biology, 55, 1-320.

Muthiga, N. A., Kawaka, J. A., \& Ndirangu, S. (2009). The timing and reproductive output of the commercial sea cucumber Holothuria scabra on the Kenyan coast. Estuarine, Coastal and Shelf Science, 84(3), 353-360.

Nuño-Hermosillo, A. (2003). Ecología poblacional, ciclo reproductivo e historia de la pesquería del pepino de mar Isostichopus fuscus (Ludwig, 1875) (Echinodermata: Holothuroidea) en Bahía Chamela, Jalisco, México. Centro Universitario de Ciencias Biológicas y Agropecuarias. Universidad de Guadalajara, México.

Omar, H. A., Abdel Razek, F. A., Abdel Rahman, S. H., \& El Shimy, N. A. (2013). Reproductive periodicity of sea cucumber Bohadschia vitiensis (Echinodermata: Holothuroidea) in Hurghada area, Red Sea, Egypt. Egyptian Journal of Aquatic Research, 39, 115-123.

Paden, C. A., Abbott, M. R., \& Winant, C. D. (1993). Tidal and atmospheric forcing of the upper ocean in the Gulf of California: 2. Surface heat flux. Journal of Geophysical Research, 98(11), 20091-20103.

Pennington, J. T. (1985). The ecology of fertilization of echinoid eggs: the consequences of sperm dilution, adult aggregation, and synchronous spawning. The Biological Bulletin, 169(2), 417-430.

Ramofafia, C., Battaglene, S. C., Bell, J. D., \& Byrne, M. (2000). Reproductive biology of the commercial sea cucumber Holothuria fuscogilva in the Solomon Islands. Marine Biology, 136(6), 1045-1056.

Ramofafia, C., Byrne, M., \& Battaglene, S. (2001). Reproductive biology of the intertidal sea cucumber Actinopyga mauritiana in the Solomon Islands. Journal of the Marine Biological Association of the UK, 81(3), 523-531.

Reyes-Bonilla, H., \& Herrero-Pérezrul, M. D. (2003). Population parameters of an exploited population of 
Isostichopus fuscus (Holothuroidea) in the southern Gulf of California, México. Fisheries Research, 59(3), 423-430.

Reyes-Bonilla, H., Ramírez-Ortiz, G., Herrero-Pérezrul, M. D., \& Calderón-Aguilera, L. E. (2016). Subestimación de la abundancia del pepino café Isostichopus fuscus (Holothuroidea: Echinodermata) en muestreos diurnos con respecto a nocturnos en el. Revista Mexicana de, 87(2), 519-522.

Safran, P. (1992). Theoretical analysis of the weightlength relationship in fish juveniles. Marine Biology, $112(4), 545-551$.

Saout, C., Quéré, C., Donval, A., Paulet, Y.-M., \& Samain, J.-F. (1999). An experimental study of the combined effects of temperature and photoperiod on reproductive physiology of Pecten maximus from the Bay of Brest (France). Aquaculture, 172(3), 301-314.

SEMARNAT. (1994). Secretaría de Medio Ambiente y Recursos Naturales. Norma Oficial Mexicana NOM059-ECOL-1994. México: Diario Oficial de la Federación (DOF), miércoles 16 de marzo de 1994.

SEMARNAT. (2002). Secretaría de Medio Ambiente y Recursos Naturales. Norma Oficial Mexicana NOM059-ECOL-2001. Diario Oficial de la Federación (DOF), miércoles 6 de marzo de 2002.

SEMARNAT. (2010). Secretaría de Medio Ambiente y Recursos Naturales. Norma Oficial Mexicana NOM059-SEMARNAT-2010. Diario Oficial de la Federación (DOF), jueves 30 de diciembre de 2010.

Servicio-Geológico-Mexicano. (2003). Carta Geológico-Minera Ensenada, H11-2 Baja California, Esc. $1: 250000$.
Shepherd, S. A., Martinez, P., Toral-Granda, M. V, \& Edgar, G. J. (2004). The Galápagos sea cucumber fishery: management improves as stocks decline. Environmental Conservation, 31(2), 102-110.

Sonnenholzner, J. I. (1997). A brief survey of the commercial sea cucumber Isostichopus fuscus (Ludwig, 1875). SPC Beche-de-Mer Information Bulletin, (March), 1995-1998.

Sonnenholzner, J. I., Brandt, M., Francisco, V., Hearn, A., Luzuruaga, M., Guarderas, P., \& Navarro, J. C. (2013). Echinoderms of Ecuador. In J. J. Alvarado \& F. A. Solís-Marín (Eds.), Echinoderm Research and Diversity in Latin America (pp. 183-233). SpringerVerlag Berlin Heidelberg.

Sonnenholzner, J. I., Searcy-Bernal, R., \& PanchanaOrrala, M. (2017). The potential for propagation of the commercial sea cucumber Isostichopus fuscus (Ludwig, 1875) by induced transverse fission. Regional Studies in Marine Science, 9, 35-42.

Soto-Mardones, L., Marinone, S. G., \& Parés-Sierra, A. (1999). Variabilidad espariotemporal de la temperetura superficial del mar en el Golfo de California. Ciencias Marinas, 25(1), 1-30.

Tapia Vázquez, O. M., Castro González, J. J., \& Valles Ríos, H. (1996). Madurez gonádica del pepino de mar Parastichopus parvimensis en la costa occidental de Baja California, México, en 1994. Ciencia Pesquera, 12, 5-12.

Toral-Granda, M. V., \& Martínez, P. C. (2007). Reproductive biology and population structure of the sea cucumber Isostichopus fuscus (Ludwig, 1875) (Holothuroidea) in Caamaño, Galápagos Islands, Ecuador. Marine Biology, 151(6), 2091-2098. 


\section{SUPPLEMENTARY MATERIAL}

TABLE 1

Descriptive statistics of the size ( $\mathrm{TL}=$ total length, $\mathrm{cm}$ and $\mathrm{W}=$ weight, $\mathrm{g}$ ) of Isostichopus fuscus on the east coast of Baja California

\begin{tabular}{|c|c|c|c|c|c|c|c|c|c|c|c|c|c|c|c|}
\hline Month & & $\mathrm{N}$ & Mean & Mode & SD & Min & Max & Month & & $\mathrm{N}$ & Mean & Mode & SD & Min & Max \\
\hline \multirow[t]{2}{*}{ Oct 2014} & $\mathrm{TL}$ & 43 & 18.54 & 21 & 5.51 & 5 & 28 & Jan 2016 & TL & 160 & 19.40 & 21 & 4.27 & 8 & 32 \\
\hline & W & 45 & 280.23 & 259 & 137.24 & 6 & 616 & & W & 158 & 231.08 & 250 & 132.26 & 20 & 760 \\
\hline \multirow[t]{2}{*}{ November } & $\mathrm{TL}$ & 122 & 21.42 & 19 & 4.82 & 7 & 34 & February & TL & 93 & 22.67 & 25 & 5.41 & 12 & 36 \\
\hline & W & 132 & 312.05 & 378 & 153.48 & 18 & 746 & & W & 93 & 360.98 & 300 & 211.26 & 60 & 1000 \\
\hline \multirow[t]{2}{*}{ December } & $\mathrm{TL}$ & 32 & 22.03 & 21 & 6.86 & 9 & 41 & March & $\mathrm{TL}$ & 140 & 22.80 & 22 & 5.60 & 9 & 36 \\
\hline & W & 32 & 360.16 & 297 & 194.57 & 28 & 739 & & W & 140 & 325.79 & 400 & 197.90 & 20 & 920 \\
\hline \multirow[t]{2}{*}{ Jan 2015} & $\mathrm{TL}$ & 154 & 15.71 & 11 & 5.9 & 6 & 35 & April & TL & 70 & 25.64 & 26 & 4.16 & 16 & 35 \\
\hline & W & 154 & 189.97 & 91 & 181.51 & 13 & 1188 & & W & 70 & 627.71 & 500 & 211.61 & 150 & 1080 \\
\hline \multirow[t]{2}{*}{ February } & $\mathrm{TL}$ & 79 & 26.1 & 25 & 4.31 & 14 & 35 & May & TL & 136 & 19.43 & 18 & 4.39 & 9 & 31 \\
\hline & W & 79 & 563.54 & 600 & 183.1 & 80 & 980 & & W & 136 & 278.16 & 360 & 156.84 & 50 & 840 \\
\hline \multirow[t]{2}{*}{ March } & $\mathrm{TL}$ & 122 & 18.2 & 12 & 6.44 & 5 & 35 & June & $\mathrm{TL}$ & 152 & 22.10 & 18 & 4.15 & 10 & 38 \\
\hline & W & 122 & 266.31 & 400 & 214.1 & 20 & 800 & & W & 152 & 373.03 & 400 & 180.64 & 50 & 1200 \\
\hline \multirow[t]{2}{*}{ April } & $\mathrm{TL}$ & 92 & 26.79 & 30 & 5.72 & 14 & 40 & July & $\mathrm{TL}$ & 163 & 21.03 & 17 & 5.80 & 4 & 36 \\
\hline & W & 92 & 588.48 & 600 & 216.57 & 40 & 1000 & & W & 162 & 416.54 & 260 & 274.41 & 10 & 1200 \\
\hline \multirow[t]{2}{*}{ May } & $\mathrm{TL}$ & 74 & 17.7 & 18 & 4.72 & 7 & 29 & August & TL & 86 & 26.65 & 26 & 4.24 & 9 & 37 \\
\hline & W & 74 & 184.38 & 100 & 183.14 & 4 & 800 & & W & 86 & 745.23 & 700 & 206.17 & 30 & 1080 \\
\hline \multirow[t]{2}{*}{ June } & $\mathrm{TL}$ & 321 & 18.56 & 16 & 6.4 & 7 & 35 & September & TL & 148 & 19.65 & 21 & 4.53 & 6 & 31 \\
\hline & W & 321 & 221.72 & 100 & 203.51 & 10 & 900 & & W & 148 & 324.46 & 300 & 141.26 & 60 & 820 \\
\hline \multirow[t]{2}{*}{ July } & $\mathrm{TL}$ & 200 & 23.36 & 21 & 5.69 & 6 & 38 & October & TL & 125 & 22.06 & 20 & 5.05 & 9 & 33 \\
\hline & W & 200 & 374.22 & 300 & 215.51 & 8 & 1200 & & W & 125 & 589.52 & 800 & 268.43 & 60 & 1200 \\
\hline \multirow[t]{2}{*}{ August } & $\mathrm{TL}$ & 133 & 22.51 & 25 & 7.33 & 9 & 40 & November & TL & 121 & 23.08 & 27 & 5.27 & 7 & 34 \\
\hline & W & 133 & 345.94 & 100 & 235.4 & 20 & 1000 & & W & 121 & 642.31 & 840 & 269.84 & 10 & 1120 \\
\hline \multirow[t]{2}{*}{ September } & $\mathrm{TL}$ & 40 & 28.58 & 26 & 4.65 & 16 & 36 & December & TL & 38 & 25.82 & 27 & 4.02 & 15 & 32 \\
\hline & W & 40 & 556 & 500 & 133.22 & 50 & 800 & & W & 38 & 427.89 & 440 & 153.84 & 120 & 800 \\
\hline \multirow[t]{2}{*}{ October } & $\mathrm{TL}$ & 30 & 23.93 & 26 & 3.12 & 14 & 28 & Pooled & TL & & 21.46 & 21 & 6.04 & 4 & 41 \\
\hline & W & 30 & 399 & 400 & 46.19 & 280 & 500 & Average & W & & 375.64 & 400 & 249.18 & 4 & 1200 \\
\hline
\end{tabular}


TABLE 2

Description of the gonadal development stages of Isostichopus fuscus

\begin{tabular}{|c|c|c|}
\hline Gonadal stage & Females & Males \\
\hline $\begin{array}{l}\text { II } \\
\text { Gametogenesis }\end{array}$ & $\begin{array}{l}\text { Oogenesis } \\
\text { Connective tissue thick, lax and undulating } \\
\text { Visible hemal sinus } \\
\text { Activity in germinal epithelium } \\
\text { Lumen empty or half empty } \\
\text { Vitellogenic oocytes } \\
\text { Primary oocytes }\end{array}$ & $\begin{array}{l}\text { Spermatogenesis } \\
\text { Connective tissue thick, lax and undulating } \\
\text { Visible hemal sinus } \\
\text { Activity in germinal epithelium } \\
\text { Lumen empty or half empty } \\
\text { Columns of primary spermatocytes orderly in wavy } \\
\text { form }\end{array}$ \\
\hline $\begin{array}{l}\text { III } \\
\text { Mature }\end{array}$ & $\begin{array}{l}\text { Mature } \\
\text { Connective tissue not visible } \\
\text { Hemal sinus not visible } \\
\text { Little or no activity of the germinal epithelium } \\
\text { Lumen filled with mature oocytes }\end{array}$ & $\begin{array}{l}\text { Mature } \\
\text { Semi lax connective tissue, poorly visible } \\
\text { Hemal sinus not visible } \\
\text { Little or no activity of the germinal epithelium } \\
\text { Lumen filled with mature spermatozoa }\end{array}$ \\
\hline $\begin{array}{l}\text { IV } \\
\text { Spawning }\end{array}$ & $\begin{array}{l}\text { Spawning } \\
\text { Connective tissue visible, fine and lax. } \\
\text { Sinus hemal barely visible. } \\
\text { Null activity of the germinal epithelium. } \\
\text { Half-empty lumen with oocyte concentration in } \\
\text { the center. } \\
\text { Residual oocytes. } \\
\text { Phagocytes }\end{array}$ & $\begin{array}{l}\text { Expulsion } \\
\text { Connective tissue visible, fine and lax. } \\
\text { Sinus hemal barely visible. } \\
\text { Null activity of the germinal epithelium. } \\
\text { Half-empty lumen, agglomeration of spermatozoa } \\
\text { in the center and empty spaces in the periphery } \\
\text { Phagocytes }\end{array}$ \\
\hline $\begin{array}{l}\text { V } \\
\text { Post spawning }\end{array}$ & $\begin{array}{l}\text { Post spawning } \\
\text { Connective tissue thick, lax and undulating } \\
\text { Visible hemal sinus } \\
\text { Little or no activity of the germinal epithelium } \\
\text { Lumen empty or half empty } \\
\text { Oocytes residual and in lysis } \\
\text { Phagocytes }\end{array}$ & $\begin{array}{l}\text { Post expulsion } \\
\text { Connective tissue thick, lax and undulating } \\
\text { Visible hemal sinus } \\
\text { Little or no activity of the germinal epithelium } \\
\text { Lumen empty or half empty } \\
\text { Spermatozoa residual and in lysis } \\
\text { Phagocytes }\end{array}$ \\
\hline
\end{tabular}

